\title{
The Analysis of Factors Influence The Production Structure in Sumatera Province
}

\author{
Zulgani $^{1}$, Rahma Nurjanah ${ }^{2}$ \\ ${ }^{1}$ FEB, University of Jambi, Jambi and Indonesia, $\square$ (e-mail) gzulgani@gmail.com \\ ${ }^{2} \mathrm{FEB}$, University of Jambi, Jambi and Indonesia, $\square$ (e-mail) rahmanurjanah@ymail.com
}

\begin{abstract}
The research entitled the analysis of factors affecting the production structure in Sumatera province. This research aims to analyze the factors affecting the production structure in Sumatera economy and to examine the effect of population variables, HDI, Special Allocation Fund (SAF), Income per capita (YCapita), FDI, Domestic Investment (DI) and Exports to services sector, primary sector, secondary sector and utility sector. Quantitative tool used is panel data regression model. The results show that these variables are generally less significant in terms of the primary sectors, utilities and secondary sectors. While the service sector, the influence of these variables is significant. It is recommended that the direction of economic development of Sumatera sector be reviewed.
\end{abstract}

Keywords: structural transformation, economic growth

\section{Introduction}

The economy of 10 provinces in Sumatra has been quite encouraging. It can be seen from the growth of agriculture sector, manufacturing industry sector, mining sector and trade, hotel and restaurant sector with contribution of 22.27 percent, 20.24 percent, 15.95 percent and 14.86 percent respectively, meanwhile in the same period the average economic growth rate for the province in Sumatra of 5.82 percent is lower than the national economic growth rate which in the same period grew by 6.32 percent (National Development Planning Agency of The Republic of Indonesia, Regional Development In Figures, 2012).

Nevertheless, during the last 5 years the economy of 10 provinces in Sumatra has decreased. This is due to the decline in prices of some primary commodities such as rubber, palm oil and coal which has been the mainstay of Sumatra's economy. The decline in commodity prices is very influential on the economic growth performance of Sumatra which in turn will also affect the economic structure of Sumatra both in the short term and in the long term. Conceptionally, the fluctuation impact of macroeconomic variables will be seen from the aspect of allocation, distribution aspect, accumulation aspect, and demography aspect. According to Kuznets, Chenery and Syrquin there are several variables that affect the changes of economic structure that is the number of population, income per capita, investment, foreign debt and exports.

The interaction of these variables in term is very influential on changes in economic structure. In relation to the above opinion, the researcher wants to study the influence of macroeconomic variables on the economic performance of the region especially viewed from the production side. According to background, the problems of this how big is the influence of population variables, per-capita GRDP, Human Development Index (IPM), Special Allocation Fund (SAF), Domestic Investment (DI), Foreign Investment (FDI) and export to the production structure of every province in Sumatera?

\section{Methods}

\section{Data Sources}

The data used in this study consisted mostly of secondary data obtained from several relevant agencies such as Bank Indonesia, especially the Regional Economic Research (KER), the annual 
Economic Report of Indonesia, from the National Development Planning Agency (BAPPENAS), the Central Bureau of Statistics (BPS) on aggregate figures of GDP, GRDP, Regional Development In Figures (PDDA), BPS Strategic Data, Indonesian Statistics and Quarterly Reports on the Indonesian Economy periodically published by the Central Bureau of Statistics (BPS).The type of data required in this study is

a. Y/capita or GDRP per capita data of provinces in Sumatra.

b. PDRB data of the provinces in Sumatra according to constant prices and prices apply based on industrial origin or by sectors

c. Data of Special Allocation Funds already distributed to all provinces in Sumatra.

d. Data Index of human development of provinces in Sumatra.

e. Export data of provinces in Sumatra.

f. Domestic Investment Data (DI) and Foreign Investment (FDI) of provinces in Sumatra.

g. Number of labor working by sector,

The above data were collected from 2000 to 2015 as well as supporting data such as Indonesia's GDP, Indonesia's economic growth rate, total export-import of goods (including oil and gas), total realized PMDNs, labor data working according to sector and education level.

\section{Data Analysis Method}

Analysis method used in this research is qualitative data analysis method, and method of quantitative data analysis. Technically, the sectors contained in GRDP are divided into 4 main sectors including:

a. Primary sector (primary sector) consisting of agriculture sector and mining and quarrying sector.

b. Industrial sectors (secondary sectors) consisting of several sub-sectors including manufacturing industry sector (including), including, and building sector (construction).

c. Utility Sector consisting of Electricity, Gas and Water Supply, Hotel and Restaurant Trade, and Transportation and Communication.

d. The service sector (tertiary sector) consisting of sectors including the financial sector, real estate banking and corporate services.

Quantitative analysis tool used in this research is panel data. From the above understanding then in this study put forward the following model: to answer the first problem used qualitative descriptive approach, while to answer the second problem used econometric approach with the model as follows:

$$
\begin{aligned}
& X_{p m} m_{i t}=\alpha_{0}+\beta_{1} L n X_{i t}+\beta_{2} E M P_{i t}+\beta_{3} H D I_{i t}+\beta_{4} L n S A F_{i t}+\beta_{5} L_{n} Y c a p_{i t}+\beta_{6} L_{n F D I}+\beta_{7} L n D I_{i t}+\varepsilon_{i t}(1) \\
& X i b_{i t}=\alpha_{0}+\delta \beta_{1} L n X_{i t}+\beta_{2} E M P_{i t}+\beta_{3} H D I_{i t}+\beta_{4} L n S A F_{i t}+\beta_{5} L n Y c a p_{i t}+\beta_{6} L_{n} F D I_{i t}+\beta_{7} L_{n D I}+\varepsilon_{i t}(2) \\
& X u t_{i t}=\alpha_{0}+\delta \operatorname{LnX} X_{i t}+\beta_{1} \operatorname{LnEMP}_{i t}+\beta_{2} H D I_{i t}+\beta_{3} S A F_{i t}+\beta_{5} \operatorname{LnYcap}_{i t}+\beta_{6} F D I_{i t}+\beta_{7} \operatorname{LnDI}_{i t}+\varepsilon_{i t}(3) \\
& X J k_{i t}=\alpha_{0}+\beta_{1} \delta L n X_{i t}+\beta_{2} L n E M P_{i t}+\beta_{3} H D I_{i t}+\beta_{4} S A F_{i t}+\beta_{5} L_{n Y c a p}+\beta_{6} F D I_{i t}+\beta_{7} L n D I_{i t}+\varepsilon_{i t}(4)
\end{aligned}
$$

Where:

$\begin{array}{ll}\alpha_{0} & =\text { Intercept } \\ \beta_{1} \mathrm{~s} / \mathrm{d} \beta_{7} & =\text { Panel Data Regression Coefficients } \\ \mathrm{Emp} & =\text { Labor } \\ \mathrm{SAF} & =\text { Special Allocation Fund } \\ \mathrm{HDI} & =\text { Human Development Index } \\ \mathrm{X} & =\text { Export }\end{array}$




$\begin{array}{ll}\text { Y / Cap } & =\text { Income Per capita } \\ \text { DI } & =\text { Domestic Investment } \\ \text { FDI } & =\text { Foreign Direct Investment } \\ \text { e } & =\text { Disturbance Error } \\ \text { Ln } & =\text { Log Natural }\end{array}$

\section{Results}

Structural transformation as an important part of long-term economic development process by Timmer (2012) suggests that structural transformation is defined as part of the process of economic growth that can be traced from (1) the decline in the contribution of the agricultural sector to Gross Domestic Product (GDP) and the decrease in labor opportunities in agriculture sector, (2) rapid urbanization process in which rural population moves to urban areas; (3) the growth and development of modern industry and service economy; (4) a demographic transition characterized by declining mortality and birth rates. The dynamic pattern of Sumatra's economy shows a significant development of changes in economic structure seen from the production side.

Other structural transformation specialists such as Chenery and Syrquin (1975), Chenery and Taylor (1968), Syrquin (1988), Kessing and Sherk (1971) in Singariya (2015) pointed out the important points of changes in economic structure are studying significant effects on structural transformation due to economies of scale, resources, and the scale of domestic demand varies greatly among countries. Besides the aspect of population density plays an important role in the pattern of trade and development. Pieper (2003) in Breisinger et al (2008) argues that economic transformation is a combination of accelerated economic growth, faster export expansion, economic diversification and structural change.

In this process, the growth of economic sectors is highly dependent on natural resources such as manufacturing industry sector, which is a potential sector and has a scale of business to grow and develop faster (Adelman 2001). The transformation of the traditional agricultural sector driven by advances in mechanical and biological technologies is also important. Specific factors that a country can play can also play a role (Hayami and Ruttan 1950).Goel and Echavaria (2015) suggests that broader structural transformation is the relocation of economic activity in the agricultural sector, the manufacturing sector, and services that accompany the process of modern economic growth.

There are many concepts of economic structural change, as Kuznets (1966) and Hughes (1992) suggest that structural transformation or economic structure change is defined as a series of changes in the composition of demand, trade, production and use of the factors necessary to maintain economic growth. Kuznets in Chenery (1979) suggests that changes in economic structure are sequences of mutually interrelated changes in the composition of aggregate demand, foreign trade (exports and imports), aggregate supply (production and use of factors of production) which is needed to support the process of development and sustainable economic growth (Tambunan, 2015, Tambunan, 2003, Tambunan, 2006, Tambunan, 2001 and Tambunan, 2008), while Anwar in Esmara (1987) does not explicitly state the concept of changes in economic structure, but with the understanding of changes in economic structure is clarified with the following description seen from the aspect of the allocation process, economic development can be considered as a process of economic growth or the process of increasing national income per capita accompanied by, among others, the transformation of a dominant economy primary sector or agriculture and mining the more dominant the industrial sector, especially the manufacturing industry or manufacturing and service industries.

Krelle in Hackle and Westlund (1991), changes in economic structure represent changes in the sectors composition of Gross Domestic Product (GDP) which includes changes in the composition of commodities from demand, changes in the structure of labor, including changes in trade relations and others. Economic structure change are proposed by Fisher (1939), Clark (1940), Kuznets (1971), and Chenery (1975), in Behera and Tiwari (2011), among others, suggest: In this regard, according to 
Kuznets, economic growth, followed by changes in economic structure, is associated as a change in the sectors composition that can be seen from changes in demand and supply side. In the meantime, Clark and Fisher argue that in the economic structure of income elasticity changes in demand for goods derived from the agricultural sector decreased with increasing income, while the elasticity of demand for non-agricultural goods increased along with rising income levels.

Tsun Se Cheong and Yanrui $\mathrm{Wu}$ (2013) in his research obtained the following results: industrialization process and tertiary industry development benefits to China's economic development. Meanwhile, Oytun Mecik and Muharrem Afsar (2014) in his research: obtained the following conclusion the significant impact (impact) of the transformation of economic structure on the labor market. Sachin Mungase (2015) in his research obtained the following result, here are many factors of heterogeneity in the process of structural transformation, some countries like India do not reach maturity as an industrial country before growth is driven by the service sector, the contribution of the service sector to GDP in SAARC member countries is higher than the average annual economic growth, and the service sector also has the highest percentage of added value to all added value.

In the meantime, Yurendra Basnett et al (2014, concludes among others: From the findings, it is found that in the long run the success of reducing poverty and developing sustainable inclusive development is highly dependent on the transformation of economic structures that can increase productive capacity. Raian Divanbeigi et al (2016) in his work declaring that the agricultural sector is truly exceptional in its role in structural transformation with characteristics of increases in productivity, changes in production composition, and renovation in commercialization.

The results of the calculation of research conducted by using the panel data regression model approach to the factors that influence the changes in the economic structure of Sumatra from the production side are as follows:

a. For the service sector, the analysis with fixed effect approach to changes ini economic structure shows the following trends.

Dependent Variable: SERVICE SECTOR

Method: Pooled Least Squares

Date: 05/11/18 Time: 06:41

Sample: 20102016

Included observations: 7

Cross-sections included: 10

Total pool (unbalanced) observations: 69

Variable

C

EXPORT?

LABOR?

HDI?

SAF?

YCAPITA?

FDI?

DI?

Fixed Effects (Cross)

-NADP $-\mathrm{C}$

_SUMUTP-C

_RIAUP-C

SUMBARP $-\mathrm{C}$
Coefficient

$-6.26168$

$-0.02074$

$-0.02427$

3.332284

0.019234

$-0.36615$

0.015923

0.003348

$-0.06744$

0.034738

$-0.26706$

0.039712
Std. Error t-Statistic Prob.

$\begin{array}{lll}2.193814 & 2.854243 & 0.0062 \\ 0.007451 & 2.784177 & 0.0075 \\ 0.036662 & 0.661868 & 0.511 \\ 0.796628 & 4.182987 & 0.0001 \\ 0.001811 & 10.62164 & 0.0000 \\ 0.078778 & 4.647896 & 0.0000 \\ 0.00465 & 3.423928 & 0.0012 \\ 0.002546 & 1.315015 & 0.1943\end{array}$




\begin{tabular}{llll}
\hline JAMBIP-C & 0.082471 & & \\
_SUMSELP_C & 0.032813 & & \\
_BENGKULUP-C & 0.130084 & & \\
_LAMPUNGP-C & 0.023057 & & \\
_KEPRIP_C & -0.02208 & & \\
_BABELP-C & 0.032295 & & 1.215474 \\
& Effects Specification & 0.209617 \\
Cross-section fixed (dummy variables) & & & -4.49125 \\
& & & -3.94082 \\
R-squared & 0.990743 & Mean dependent var & -4.27287 \\
Adjusted R-squared & 0.987894 & S.D. dependent var & 1.608443 \\
S.E. of regression & 0.023063 & Akaike info criterion \\
Sum squared resid & 0.02766 & Schwarz criterion & \\
Log likelihood & 171.948 & Hannan-Quinn criter. \\
F-statistic & 347.8203 & Durbin-Watson stat & \\
Prob(F-statistic) & 0.00000 & &
\end{tabular}

The above data provide the following information: there are 5 main variables, among others: export, special fund allocation (SFA), income per capita, HDI and FDI affecting changes in economic structure seen from the service sector with interpretation: if the export variable increased by 1 percent, service sector of -0.02 percent (this variable has a negative effect), for the HDI variable, if the HDI variable grows by 1 percent then, the service sector in the sumatera economy increases by 3.33 percent (this variable has a positive effect), meanwhile for the variable SFA, the effect is positive where if SFA increases by 1 percent will change the service sector by 0,019 percent, the next for variable income per capita, the effect on service sector contribution is negative, meaning if variable per capita income increased by 1 percent then, by 0.37 percent.

For the FDI variable, its influence on service sector development is positive, meaning if the FDI variable increases by 1 percent, the service sector contribution will increase by 0.02 percent. The value of $\mathrm{R}$ squared of 0.987894 gives the meaning that simultaneously almost all independent variables have a significant influence on service sector development (almost 99 percent).

Meanwhile, for $\mathrm{F}$ test, it also shows that all independent variables have significant effect on dependent variable (in this case development of service sector). The Fixed Effect model is selected after Chow test (for choice between fixed effect or PLS), while for the choice between FEM and REM (Hausman test has been done, FEM decision is fixed using model.

b. The Primary Sector, the analysis used still uses the Fixed Effect Model approach, because after being tested both with Chou Test (determining which one is best of PLS and FEM and Hausman's test to determine which model is best between FEM and REM), the decision remains on the model FEM is best. The results of data processing include:

Dependent Variable: PRIMARY SECTOR

Method: Pooled Least Squares

Date: 05/11/18 Time: 11:20

Sample: 2010 - 20016

Included observations: 7

Cross-sections included: 10

Total pool (balanced) observations: 70

\begin{tabular}{lllll} 
Variable & Coefficient & Std. Error & t-Statistic & Prob. \\
C & 27.25758 & 6.543265 & 4.165747 & 0.0001 \\
\hline
\end{tabular}




\begin{tabular}{lllll}
\hline EXPORT? & 0.007328 & 0.010589 & 0.69204 & 0.4919 \\
LABOR? & -0.04074 & 0.140234 & -0.290545 & 0.7725 \\
HDI? & -7.42311 & 2.157794 & -3.44014 & 0.0011 \\
SAF? & -0.00479 & 0.006079 & -0.787505 & 0.4345 \\
YCAPITA? & 0.466228 & 0.214271 & 2.175886 & 0.0340 \\
FDI? & -0.00259 & 0.01477 & -0.175447 & 0.8614 \\
DI? & 0.005752 & 0.008168 & 0.704194 & 0.4844 \\
Fixed Effects (Cross) & & & & \\
_NADP-C & 0.292569 & & & \\
_SUMUTP--C & -0.22767 & & & \\
_RIAUP--C & 0.153284 & & & \\
_SUMBARP--C & 0.031844 & & & \\
_JAMBIP--C & 0.267835 & & & \\
_SUMSELP--C & 0.016721 & & & \\
_BENGKULUP--C & 0.170422 & & & \\
_LAMPUNGP--C & 0.018548 & & & \\
_KEPRIP--C & -0.58 & & & \\
_BABELP--C & -0.14356 & & &
\end{tabular}

Effects Specification

Cross-section fixed (dummy variables)

$\begin{array}{llll}\text { R-squared } & 0.952623 & \text { Mean dependent var } & 3.558043 \\ \text { Adjusted R-squared } & 0.93832 & \text { S.D. dependent var } & 0.302455 \\ \text { S.E. of regression } & 0.075116 & \text { Akaike info criterion } & -2.13206 \\ \text { Sum squared resid } & 0.299046 & \text { Schwarz criterion } & -1.586 \\ \text { Log likelihood } & 91.62218 & \text { Hannan-Quinn criter. } & -1.91516 \\ \text { F-statistic } & 66.60524 & \text { Durbin-Watson stat } & 2.213368 \\ \text { Prob(F-statistic) } & 0.00000 & & \end{array}$

From the results of the above data obtained the explanation as follows: there are only two independent variables, namely HDI and income per capita that significantly influence the development of the primary sector, the remaining econometric 5 other independent variables have no significant effect on the development of the primary sector. The interpretation for the HDI variable is if it increases by 1 percent, the primary sector will decrease by -7.42 percent (this variable has a negative effect), whereas for the income variable per capita, if per capita income increases by 1 percent then the primary sector will increase by 0, 47 percent. The Fixed Effect model is chosen after Chow test (for choice between fixed effect or PLS), while for FEM and REM (Hausman test is done, FEM decision is fixed using REM model 0.952623 indicates the ability of independent variable to explain its influence on the development of the dependent variable (primary sector) of 95 percent, the rest is determined by other factors outside the model For F test, the result shows that almost all free variables affect the dependent variable (2 significant and 5 not significant).

c. Utility Sector, the results of data processing with panel regression model approach to see the effect of independent variables on the dependent variable on the utility sector in the structure of the economy of Sumatra is as follows : 
Dependent Variable: UTILITY SECTOR

Method: Pooled Least Squares

Date: 05/11/18 Time: 13:53

Sample: 20102016

Included observations: 7

Cross-sections included: 10

Total pool (unbalanced) observations: 69

Variable Coefficient

$\mathrm{C}$

EXPORT?

LABOR?

HDI?

SAF?

YCAPITA?

FDI?

DI?

Fixed Effects (Cross)

_NADP $-\mathrm{C}$

0.291238

_SUMUTP--C

0.412919

_RIAUP-C

$-0.57787$

_SUMBARP--C

0.384126

JAMBIP-C

$-0.18169$

_SUMSELP--C

0.064171

_BENGKULUP--C

0.169809

_LAMPUNGP--C

0.357846

_KEPRIP-C

$-0.82488$

BABELP-C

$-0.07142$

Std. Error t-Statistic

$\begin{array}{rll}12.98444 & -2.014219 & 0.0492 \\ 0.036714 & 1.361373 & 0.1793 \\ 0.247607 & -0.622281 & 0.5365 \\ 4.944584 & 1.73194 & 0.0892 \\ 0.010567 & -8.016419 & 0.0000 \\ 0.460264 & -0.50673 & 0.6145 \\ 0.027557 & -0.719282 & 0.4752 \\ 0.01503 & -0.912778 & 0.3656\end{array}$

Effects Specification

Cross-section fixed (dummy variables)

$\begin{array}{lrcl}\text { R-squared } & 0.912535 & \text { Mean dependent var } & 2.838155 \\ \text { Adjusted R-squared } & 0.885623 & \text { S.D. dependent var } & 0.406958 \\ \text { S.E. of regression } & 0.137632 & \text { Akaike info criterion } & -0.91858 \\ \text { Sum squared resid } & 0.985013 & \text { Schwarz criterion } & -0.36814 \\ \text { Log likelihood } & 48.69088 & \text { Hannan-Quinn criter. } & -0.7002 \\ \text { F-statistic } & 33.9077 & \text { Durbin-Watson stat } & 1.049549 \\ \text { Prob(F-statistic) } & 0 & & \end{array}$

From the results, it can be interpreted as follows: there are only two independent variables that significantly influence the development of utilities sector in the economy of Sumatra, HDI and SAF variables, the remaining 5 independent variables did not affect the development of utility sector. The HDI variable has a positive and significant effect on the utility sector, meaning that if HDI increases by 1 percent then the utility sector will increase by 8.56 percent, while for SAF, the effect is negative and significant on the utility sector, if SAF increases by 1 percent then the utility sector will decrease by -0.08 percent. Meanwhile, for $\mathrm{R}$ squared value of 0.885623 means the ability of independent 
variables to explain the effect on the dependent variable of 89 percent, the rest is explained by other variables not listed in this model, then for $\mathrm{F}$ test, the results show almost all independent variables affect the variable bound. The Fixed Effect model was chosen after Chow test (for which option is the best between fixed effect or PLS), whereas for the choice between FEM and REM (Hausman test has been done, the decision is still using FEM model.

d. Secondary Sector, the results of data processing with panel regression model approach to see the effect of independent variables on the dependent variable on the secondary sector in the structure of the economy of Sumatra is as follows:

Dependent Variable: SECONDARY SECTOR

Method: Pooled Least Squares

Date: 05/11/18 Time: 13:28

Sample: 20102016

Included observations: 7

Cross-sections included: 10

Total pool (unbalanced) observations: 69

Variable Coefficient

C

EXPORT?

LABOR?

HDI?

SAF?

YCAPITA?

FDI?

DI?

Fixed Effects (Cross)

$\begin{array}{lr}\text { _NAAP-C } & -0.386552 \\ \text { _SUMUTP--C } & 0.295924 \\ \text { _RIAUP-C } & 0.228403 \\ \text { _SUMBARP--C } & -0.328428 \\ \text { _JAMBIP--C } & -0.308188 \\ \text { _SUMSELP--C } & 0.325404 \\ \text { _BENGKULUP--C } & -0.91091 \\ \text { _LAMPUNGP--C } & 0.101633 \\ \text { _KEPRIP--C } & 0.646201 \\ \text { _BABELP--C } & 0.206383\end{array}$

Effects Specification

0.206383
Std. Error

0.0492

0.016773

$-0.049404$

5.160244

0.008305

$-0.239956$

0.006058

$-0.0038$ t-

Statistic

7.119133

$-2.01411$

0.015083

0.124099

1.112064

$-0.3981$

2.475904

2.084186

0.0082

1.012798

$-1.09424$

0.338774

$-0.32346$

Prob.

0.21929

0.017883

0.011749
0.2712

0.6922

0.0421

0.3158

0.2789

0.7361

0.7476

Cross-section fixed (dummy variables)

R-squared

0.953541

Adjusted R-squared
Mean dependent var

S.D. dependent var
3.222486

0.42950 


$\begin{array}{lccr}\text { S.E. of regression } & 0.105866 & \text { Akaike info criterion } & -1.4434 \\ \text { Sum squared resid } & 0.582793 & \text { Schwarz criterion } & -0.89297 \\ \text { Log likelihood } & 66.79729 & \text { Hannan-Quinn criter. } & -1.22503 \\ \text { F-statistic } & 66.70422 & \text { Durbin-Watson stat } & 1.38659 \\ & & & 4 \\ \text { Prob(F-statistic) } & 0 & & \end{array}$

From the data above, it can be explained that there is only 1 independent variable that significantly affect the secondary sector in the economy of Sumatra. The variable is HDI, with the following interpretation: if the HDI variable increases by 1 percent then the secondary sector in the Sumatran economy will increase by 5.16 percent (positively and significantly), while the other 6 independent variables have no effect on the dependent variable. For R squared of 0.953541 means that 95 percent of variations in secondary sector variables are due to independent variables, the remaining about 5 percent is determined by other variables outside the model. For Test F, indicates that simultaneously the variables affect the dependent variable.

\section{Conclusions}

From the above discussion it can be concluded that changes in the economic structure seen from the side of production has not been so in line with the theory of changes in economic structure as developed by Chenery and Syrquin. The contribution of free variables such as exports, HDI, SAF, per capita income, FDI and DI, to the development of primary, secondary and utilities sectors is less significant. This condition will allow the process of changing the economic structure of Sumatera will not run significantly and slowly. It is therefore necessary to reorient the overall direction of economic development of Sumatera in order to create a strong foundation for the creation of a strong economic structure change.

\section{References}

Adelman, (2001). Fallacies in the Development Theory and Their Implications for Policy dalam G.M.Meier dan J.E.Stiglitz (eds) Frontiers of Development Economics: The Future Perspective. Oxford University Press: New York.

Basnet, Y et al, (2014). Structural economic trransformation in Nepal: a diagnostic study. Submitted to DFID Overseas Development Institute Blackfriars Road. London.

Behera Depak Kumar dan Mitali Tiwari, (2011). Structural transformation in india: an economteric investigation, Ministry of Home Affairs Government of India. New Delhi.

Breisinger at al, (2008). Accelerating growth and structural transformation ghana's option for reaching middle income country status. International Food Policy Research Institute, Washington, USA.

Cheong, T. S., dan Yanrui, Wu. (2013). The impact of structural transformation and industrial uprgading on regional inequality in china. The University of Western Australia. Discussion Paper 14(09).

Divanbeigi, $\mathrm{R}$ et al, (2016). Structural transformation of the agricultural sector; a primer. research policy briefs from the world bank malaysia hub.(2).

Esmara, H. (1987). Economic Theory and Development Policy. Gramedia Publisher, First Edition

Ferde, Tadele. (2015). Sectoral economic growth and structural transformation in ethiopia. Departement of Economics Addis Ababa University.

Goel dan Echavaria, (2015). India's a typical structural transformation, economic synopses. The Federal Reserve bank : St Louis Number 23

Hackl, P and Westlund, A. H. (1991). Economic Structural Change Analysis and Fofrecasting. SpringerVerlag: Germany.

Hayami and Rutan. (1950). Agricultural Development: An International Perspective. Baltimore John Hopkins University Press. 
Hughes, H. (1992). The Success of Industrialization in East Asia.PT.Gramedia Pustaka Utama Publisher, First Edition.

Mecik, O and Afsar, M. (2014). The effect of structural transformations in economy on labor market: the case of OECD countries. International l Jurnal of Business and Social Science. 9(1).

Mungase, Sachin. (2015). Growth and structural transformation in SAARC economies. The Business and Management Review.5(4).

National Development Planning Agency of The Republic of Indonesia, (2012). Regional Development In figures 2012.

Singariya, (2015). Dynamic Pattern of Structural Change and Economic Growth During the High Growth Regime in India: A Panel Data Analysis. International Journal of Econometrics and Financial Management.3(2).

Tambunan, T. (2001)The Indonesian Economy. Empirical, Theories and Findings. Ghalia Indonesia Publisher, Second Edition.

Tambunan, T. (2003)b. The Indonesian Economy: Some Important Issues. Ghalia Indonesia Publisher. First Edition.

Tambunan, T and Tahi, H. (2008)Economic Development and Foreign Debt. Rajawali Press Publisher, First Edition.

Tambunan Tulus and Tahi.H, (2015)d. Indonesia's Economy Era Old Order untill Jokowi. Ghalia Indonesia Publisher, First Edition.

Tambunan, T. (2006) Indonesia's. Economy Since the Old Order Post Crisis. Pustaka Quantum Publisher. First Edition.

Timmer P, (2012). The Mathematics of Structural Transformation. West Central Africa Office. Thematic Research Note. 